\title{
Intake of total fat, saturated, monounsaturated and polyunsaturated fatty acids in an Irish adult population
}

\author{
A. M. Tierney, B. A. McNulty, A. P. Nugent and M. J. Gibney \\ UCD Institute of Food and Health, University College Dublin, Belfield, Dublin 4, Ireland
}

The relationship between intakes of dietary fatty acids and the onset of chronic diseases such as obesity and cardiovascular disease is well established $^{(1)}$, with several countries having established population recommendations for intakes ${ }^{(2)}$. This analysis aimed to update the National Adult Nutrition Survey (NANS) database with accurate estimates of total fat, saturated fat (SFA) monounsaturated fat (MUFA) and polyunsaturated fat (PUFA) and to quantify intakes. The NANS examined habitual food and beverage intake in a representative sample of Irish adults during 2008-2010. Manufacturer's information and updated food composition information was used to update the database. Fat intakes were also compared with the North South Ireland Food Consumption Survey (NSIFCS) ${ }^{(3)}$. Excluding underreporters, the final NANS sample consisted of 1051 adults (889 aged 18-64 y, 162 aged >65y) and the NSIFCS of 1097 adults. In addition, compliance with dietary recommendations and main food sources contributing to dietary fat intake were also analysed.

\begin{tabular}{|c|c|c|c|c|c|c|}
\hline & \multirow{2}{*}{\multicolumn{2}{|c|}{$\begin{array}{c}\text { NSIFCS } 2001 \\
18-64 \mathrm{y} \\
(n=1097) \\
\end{array}$}} & \multicolumn{4}{|c|}{ NANS 2011} \\
\hline & & & \multicolumn{2}{|c|}{$\begin{array}{c}18-64 \mathrm{y} \\
(n=889) \\
\end{array}$} & \multicolumn{2}{|c|}{$\begin{array}{c}>65 \\
(n=162)\end{array}$} \\
\hline & Mean & SD & Mean & SD & Mean & SD \\
\hline $\begin{array}{l}\text { Total fat } \\
\text { g/day } \\
\% \text { Total energy }\end{array}$ & $\begin{array}{l}96.1 \\
35.8\end{array}$ & $\begin{array}{r}30.5 \\
5.4\end{array}$ & $\begin{array}{l}86.6^{*} \\
34.1^{*}\end{array}$ & $\begin{array}{r}28.0 \\
6.2\end{array}$ & $\begin{array}{l}73.7 \\
34.8\end{array}$ & $\begin{array}{r}29.7 \\
7.0\end{array}$ \\
\hline $\begin{array}{l}\text { Saturated fat } \\
\text { g/day } \\
\% \text { Total energy }\end{array}$ & $\begin{array}{l}37.8 \\
14.0\end{array}$ & $\begin{array}{r}14.3 \\
3.1\end{array}$ & $\begin{array}{l}33.9^{*} \\
13.3^{*}\end{array}$ & $\begin{array}{r}12.4 \\
3.3\end{array}$ & $\begin{array}{l}30.6 \\
14.4\end{array}$ & $\begin{array}{r}14.9 \\
4.2\end{array}$ \\
\hline $\begin{array}{l}\text { Monounsaturated fat } \\
\text { g/day } \\
\% \text { Total energy }\end{array}$ & $\begin{array}{l}32.2 \\
12.0\end{array}$ & $\begin{array}{r}10.6 \\
2.0\end{array}$ & $\begin{array}{l}31.9^{*} \\
12.5\end{array}$ & $\begin{array}{r}11.1 \\
2.6\end{array}$ & $\begin{array}{l}25.8 \\
12.2\end{array}$ & $\begin{array}{r}10.8 \\
2.9\end{array}$ \\
\hline $\begin{array}{l}\text { Polyunsaturated fat } \\
\text { g/day } \\
\% \text { Total energy }\end{array}$ & $\begin{array}{r}18.7 \\
7.0\end{array}$ & $\begin{array}{l}7.3 \\
2.3\end{array}$ & $\begin{array}{r}15.3^{*} \\
6.0^{*}\end{array}$ & $\begin{array}{l}6.7 \\
2.2\end{array}$ & $\begin{array}{r}12.1 \\
5.8\end{array}$ & $\begin{array}{l}5.6 \\
2.3\end{array}$ \\
\hline P:S ratio & 0.53 & 0.22 & $0.48^{*}$ & 0.23 & 0.44 & 0.21 \\
\hline
\end{tabular}

* Significant differences $(<0.05)$ between NSIFCS 18-64 y and NANS 18-64 y (Independent Samples t-test). P:S ratio; Ratio of polyunsaturated to saturated fat.

Adults aged 18-64 y had slightly lower intakes (\% total energy) of total fat and SFA, but higher intakes of MUFA and PUFA than adults aged $>65 \mathrm{y}$. The P:S ratio of 0.48 in $18-64 \mathrm{y}$ exceeded the recommendation of between 0.23 and $0.45^{(4)}$. The percentage of the population complying with UK dietary SFA recommendations was poor (35.1\% and $30.2 \%$ for $18-64 \mathrm{y}$ and $>65 \mathrm{y}$ respectively). Key food sources contributing to SFA intakes in 18-64 year olds were fresh meat (8.7\%), biscuits cakes, pastries and buns $(8.3 \%)$, and cheeses $(8.1 \%)$. When compared to NSIFCS, significant reductions in total fat, SFA and PUFA intakes were observed in NANS. In parallel, there was an increase in the percentage of adults complying with recommended intakes for total fat (from 67\% to 91.5\%) and SFA (21\% to $35 \%$ ). These results indicate that while compliance with total fat and SFA recommendations has increased, the quality of fat intake amongst Irish adults still deviates from population recommendations.

1. Lichtenstein AH, Kennedy E, Barrier P et al. (1998) Nutr Rev 56, S3-S28.

2. EFSA Journal (2010) 8(3), 1461.

3. Joyce T, Wallace AJ, McCarthy SN et al. (2008) Public Health Nutr 12(2), 156-165.

4. Goldberg GR, Black AE, Jebb SA et al. (1991) Eur J Clin Nutr 45, 569-81.

5. Department of Health (1984) Diet and Cardiovascular Disease. Committee on Medical Aspects of Food Policy Report on Health and Social Subjects no. 28. London: HMSO. 